DOI: https://doi.org/10.32839/2304-5809/2021-4-92-15

УДК 811.134 .2

Маркова I.B.

Херсонський державний університет

\title{
СУЧАСНІ МЕТОДИ ФОРМУВАННЯ ЛЕКСИЧНОЇ КОМПЕТЕНТНОСТІ НА УРОКАХ ІСПАНСЬКОЇ МОВИ В ГІМНАЗІЇ
}

Анотація. В умовах сучасності, все більше актуальності набуває компетентісний підхід до вивчення іноземних мов. Наразі існуе потреба суспільства в кваліфікованих фрахівцях, здатних вступати в іншомовне спілкування. В таких умовах, процес навчання повинен бути спрямований на пошук нових, інтерактивних прийомів, що стимулюють учнів до породження грамотно оформленого усного чи писемного висловлювання. У статті висвітлені сучасні методи формування лексичної компетентності на уроках іспанської мови в гімназії. Схарактеризовано структуру лексичної компетентності учнів. Вивчено сучасні підходи та технології формування лексичної компетенщії учнів основної школи. Також було розроблено систему вправ $з$ метою формування усної та письмової лексичної компетентності учнів гімназії на уроках іспанської мови. Проаналізовано використання методик змішаного навчання учнів гімназії на уроках іспанської мови.

Ключові слова: лексична компетентність, іспанська мова, система вправ, змішане навчання, методика.

Markova Iryna Kherson State University

\section{MODERN METHODS OF THE FORMATIONS OF LEXICAL COMPETENCE AT THE SPANISH LESSONS IN THE GYMNACIUM}

Summary. In modern conditions, the competence approach to the study of foreign languages is becoming increasingly important. At present, there is a need of the society for qualified specialists capable of entering into foreign language communication. In such conditions, the learning process should be aimed at finding new, interactive techniques that encourage students to generate a well-designed oral or written expression. The article highlights modern methods of forming lexical competence in Spanish lessons in the gymnacium. The paper considers approaches to defining the concept of lexical competence and its role in learning a foreign language. In the course of the analysis, we found that there are many definitions of lexical competence, but still scientists cannot reach a unanimous decision. Therefore, we focused on specific definitions of concepts and analyzed them to identify commonalities and differences between them. The structure of lexical competence of pupils is characterized. The components of lexical activity were classified according to the following elements: oral language, written language, technical language (telegraph, radio, telephone, television, computer), which is differentiated by areas (household, business, scientific, political, religious, aesthetic, artistic), genres (each sphere of language has its own repertoire of language genres). Peculiarities of formation of lexical competence of secondary school pupils are determined. Modern approaches and technologies of formation of lexical competence of secondary school pupils are studied. A system of exercises was also developed in order to form oral and written lexical competence of high school pupils in Spanish lessons. The use of methods of mixed learning of high school pupils in Spanish lessons is analyzed, based on an experimental study of the effectiveness of methods of forming foreign lexical competence in pupils of gymnacium in Spanish lessons both online (Zoom platform) and offline (directly in classrooms). The theoretical basis of the work were the pupils of prominent domestic and foreign scientists, such as: I.I. Khaleeva, G.P. Miltrud, E.V. Nosonovich, O.B. Bigich, O.V. Bolotov, O. Vetokhov, I.O. Winter, L.I. Cyril, R.L. Oxford, R.C. Scarcella, S. Walter, A. Gilmore, and others.

Keywords: lexical competence, Spanish language, system of exercises, mixed learning, methods.

Постановка проблеми. Наразі існуе потреба суспільства в кваліфікованих фрахівцях, здатних вступати в іншомовне спілкування. В таких умовах, процес навчання повинен бути спрямований на пошук нових, інтерактивних прийомів, що стимулюють учнів до породження грамотно оформленого усного чи писемного висловлювання. Не дивлячись на розробленість цієї теми, залишається ряд спірних і невирішених питань щодо підходів, методів та технології розвитку лексичної компетенції учнів. Також, існуе необхідність пошуку нових методик формування та розвитку лексичної компетенції на уроках іспанської мови.

Аналіз досліджень. Було проаналізовано багато теоретичних джерел, і саме роботи таких науковців, як I. I. Халєева, Г. П. Мільтруд, Є. В. Носонович, О. Б. Бігич, О. В. Болотов, О. Ветохов, I. О. Зимня, Л. I. Кириліна, R. L. Oxford, R. C. Scarcella, C. Walter, A. Gilmore та інших стали теоретичним підгірунтям нашого дослідження.
Мета статті полягае у вивченні та дослідженні методики формування іншомовної лексичної компетентності в учнів гімназії на уроках іспанської мови.

Виклад основного матеріалу. В умовах сучасності, все більше актуальності набуває компетентісний підхід до вивчення іноземних мов. Актуальність реалізації компетентнісного підходу викликана:

- переходом на нову освітню парадигму;

- впровадженням нових програм в освітній процес перевиданням старих і появою нових навчально-методичних комплексів з урахуванням сучасних вимог;

- оріентаціею шкільної освіти на формування ключових компетенцій;

- неефективність парадигми знань: відсутністю в учнів практичних навичок.

У педагогічних дослідженнях, лексична компетентність трактуеться як знання, вміння та нави- 
чки, необхідні для розуміння чужих і породження своїх власних програм мовної поведінки, адекватної полям, сфрерам, ситуаціям спілкування, і як сукупність знань про систему мови, її фрункції, устрій, вміння і навички нормативного використання мовних засобів для досягнення орфографрічної, пунктуаційної та мовної грамотності [4, с. 157].

Наразі, формування лексичної компетентності учнів основної школи відбувається за допомогою рівневого навчання. Рівневе навчання іноземним мовам з'явилося у вітчизняній методиці та практиці викладання іноземних мов порівняно нещодавно. До цього методисти, вчителі та викладачі у своїх працях і в процесі навчання орієнтувалися на «середнього учня».

У системі загальноєвропейських концепщій рівневого володіння мовою (CEFR) (Common European Framework of Reference: Learning, Teaching Assessment) знання та вміння учнів поділяються на три великі категорії, які далі поділяються на шість рівнів [6, с. 14]. Німецький вчений Д. Трім також називає шість основних рівнів:

- A1 (Breakthrough);

- A2 (Waystage);

- B1 (Threshold);

- B2 (Vantage);

- C1 (Effective Operational Proficiency);

C2 (Mastery) [10, c. 45].

Експертами була розроблена як система рівнів володіння мовою, так і система дескрипторів (опису цих рівнів) з використанням стандартних категорій. Ці два комплекси створюють єдину мережу понять, яка може бути використана для опису будь-якої системи сертифікації, а отже і будь-якої програми навчання [6, с. 14].

У системі рівневого навчання CEFR передбачена і можливість для кожного учня самому визначати свій рівень володіння іноземною мовою, програмувати подальшу роботу, констатувати свої сильні і слабкі сторони. Для викладача, відповідно, продумана система вправ і тестів для організапії успішної роботи індивідуально і в групі учнів [7, с. 134].

Отже, одним з важливих завдань в ході викладання іноземної мови є виявлення та врахування індивідуальних потреб і здібностей учнів, пошук технологій їх творчого розвитку та реалізації.

Особливе місце в рівневій системі посідає самостійна робота учнів та їі організація з урахуванням диференціації навчального матеріалу, застосування ресурсів IКТ та потенційних можливостей учнів. Проблема організації та виконання самостійної роботи містить певні труднощі і для вчителів, i для учнів. Труднощі учнів часто пов'язані з відсутністю навичок виконання самостійних робіт, низькою мотивацією, відсутністю інтересу до виконання роботи, невмінням чітко розподілити свій час.

Що стосується вчителів, то їх проблеми в організацї самостійної роботи учнів вбачаються в одноманітних видах самостійних робіт, що носять в основному репродуктивний характер (робота 3 текстами, пошук літератури, підготовка доповіді, участь у конфреренщіі), при цьому дослідницькі та проєктні завдання використовуються недостатньо.

Таким чином, рівневий підхід до навчання іноземних мов характеризуеться чітким розумінням кінцевих цілей для кожного 3 рівнів воло- діння іноземною мовою, поступовістю навчання, прозорістю і об'єктивністю оцінки знань учнів в рамках кожного рівня [2, с. 5].

У роботі з форомування лексичної компетенції необхідно «Поєднувати різні види вправ і методи роботи і використовувати всі доступні сучасні засоби в їх творчому поєднанні», одночасно розвиваючи всі види мовленнєвої діяльності учнів.

Формування лексичної компетентності характеризуеться значним обсягом технологій та підходів до їі форомування. Автор популярного підручника Global Ліндсей Клендфілд головною умовою для формування лексичної компетентності, ставить застосування критичного мислення, а також підбір відповідного матеріалу, який зміг би сприяти розвитку лексичної компетентності учнів [8, с. 97].

З огляду на те, що критичне мислення є надзвичайно важливим елементом формування лексичної компетентності учнів, розглянули особливості впровадження в хід занять вправ на основі його активізації. Критичне мислення включає в себе наступні фрази: фрактична оцінка ситуації, її опис та аналіз, інтерпретація, пояснення, логічні висновки і прогнозування подій [5]. Головне завдання викладача - вдало поєднувати ці технології, з метою отримання позитивних результатів.

На прикладі типових завдань ми виділили такі прийоми формування усної лексичної компетентності: «понятійне колесо» - практичне застосування даного прийому може сприяти для активізації розумової діяльності учнів на початковому етапі навчального заняття [1, с. 4]; прийом «за і проти» - метою даного прийому $\epsilon$ розвиток мовних компонентів, висловлювання своїх точок зору на задану тему; метод кластерів - застосування кластера в кінці навчального заняття для закріплення лексичного матеріалу $€$ найбільш ефективним [3, с. 2]; прийом «опис фотографій» 3 використанням плану-кліше слугує для ефрективного розвитку критичного мислення та розвитку мовленневих навичок.

Письмову лексичну компетентність учнів краще за все формувати за допомогою виконання неомунікативних і умовно-комунікативних вправ, наведених у розділі.

Далі ми будемо аналізувати результати ефективності методики формування іншомовної лексичної компетентності в учнів гімназї на уроках іспанської мови як он-лайн (платфрорма Zoom) так і офрлайн (безпосередньо в навчальних аудиторіях), які були проведені на експериментальному дослідженні.

Мета цього експерименту полягала в дослідженні ефрективності методики впровадження у навчальний процес комплексу завдань, направлених на формування іншомовної лексичної компетентності в учнів гімназії на уроках іспанської мови.

Експериментальне дослідження проводилося серед учнів 6 класів Херсонській спеціалізованій школі I-III ступенів № 54 з поглибленим вивченням іспанської та інших іноземних мов Херсонської міської ради. Для спостереження було обрано дві підгрупи з класу. В експерименті брали участь 18 школярів. Ми вибрали такий клас, в якому були присутні різні за рівнем навчання діти.

Отже, наше дослідження складалося з трьох етапів. Перший етап - підготовчий. Було прове- 
дено першу діагностику на основі вправ, розробка уроків (фрагментів уроків), збір інформації про рівень лексичної компетентності учнів.

Другий етап складався з впровадження власне уроків в навчальній аудиторії й на платформі Zoom.

На третьому, завершальному етапі, ми зіставили результати першого и другого спостереження, та зробили висновки про результативність використання вищерозглянутих завдань в процесі формування іншомовної лексичної компетентності в учнів гімназії на уроках іспанської мови.

Отже, таких результатів ми досягли. 3 метою виявлення рівня сформованості вимовних умінь і навичок в досліджуваному класі було проведено вхідний контроль. Учням пропонувалося виконати різноманітні вправи. На основі зібраних даних були виявлені наступні переваги та недоліки змішаного навчання.

Результати підсумкового контролю показали, що платформа Zoom має більший спектр використання цифрових технологій. Тобто для онлайн-уроків ми робили в електронному виді, створювали тести в Google Forms, взагалі ми не використовували роздрукований матеріал, що набагато скоротило час на підготовку та грошей.

У другому пункті ми простежили технічне обладнання i виявили, що в навчальних аудиторіях менше збоїв з технікою. Тобто неважливі збої зі зв'язком, світлом і таке інше. У той час на платформі Zoom такі проблеми душе часті і на жаль на це неможливо ніяк вплинути.

Також простежується позитивна динаміка в емоційній складовій уроку саме на офрлайн уроці. В середньому на 40 \% менше учнів відчували складнощі у висловлюванні власних думок в навчальній аудиторіі. Звичайно, не можна сказати, що учні, на платдормі Zoom не могли висловити свою точку зору, проте, очно вони робили це більш жваво, емоційно, навіть відбувався диспут.

Останне, на що ми звернули увагу - це доступ до інформаційних джерел. В ході дослідження, було з'ясовано, що на платформі Zoom учні мають більше доступу до різних джерел (інтернет ресурси, допоміжна література). А у навчальній аудиторії цей доступ обмежений.

В практиці своєї роботи вчителям необхідно приділяти велику увагу формування лексичної компетентності як на онлайн-уроках та і на офрлайн-уроках, оскільки без подальшої роботи лексичною компетентністю в учнів, вона дуже швидко знизиться. Таким чином, в ході наполегливої систематичної роботи вчитель та учні неодмінно досягнуть значних результатів у роботі над формуванням усної та писемної лексичної компетентності в ході вивчення іспанської мови.

Висновки. Роботу присвячено дослідженню особливостей формування іншомовної лексичної компетентності в учнів 33СО на уроках іспан- ської мови. Дослідження теоретичних джерел дало змогу зробити висновок про те, що наразі поняття «компетенція» розуміеться як сукупність знань, умінь i/або навичок, певних якостей особистості та обізнаність в рамках тієї чи іншої теми (предмета, процесу, сфери діяльності, тощо), що в своїй єдності допомагає вирішувати практичні завдання, забезпечуючи діяльність людини.

Було зазначено, що поняття «лексична компетентність» сучасні дослідники визначають як як рівень володіння основними вміннями і навичками всіх видів мовленневої діяльності в життево важливих для спілкування в усіх copepax i жанрах. Педагоги ж трактують лексичну компетентність як знання, вміння та навички, необхідні для розуміння чужих і породження своїх власних програм мовної поведінки, адекватної полям, сфрерам, ситуаціям спілкування, і як су-

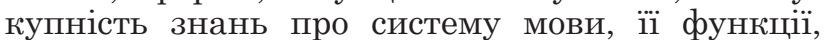
устрій, вміння і навички нормативного використання мовних засобів для досягнення орфографрічної, пунктуаційної та мовної грамотності.

Аналіз теоретичних джерел показав, що до основних компонентів лексичної діяльності відносять наступні елементи: усна мова; письмова мова; технічна мова. Формування лексичної компетентності учнів основної школи відбувається за допомогою рівневого навчання, яке включає в себе 6 основних рівнів: A1 (Breakthrough); A2 (Waystage); B1 (Threshold); B2 (Vantage); C1 (Effective Operational Proficiency); C2 (Mastery).

Також було розроблено методику формування лексичної компетентності учнів під час вивчення іспанської мови. Всі вправи було розподілено за формуванням усної та письмової лексичної компетентності.

I останне. Найбільшій увазі було присвячено аналізу ефективності методики змішаного навчання у фрормуванні іншомовної лексичної компетентності в учнів 33СО на уроках іспанської мови.

Під час проходження педагогічної практики у Херсонській спеціалізованій школі I-III ступенів № 54 з поглибленим вивченням іспанської та інших іноземних мов Херсонської міської ради ми зробили спробу порівняти результати офлайн та онлайн уроку в експериментальних групах 6 класу 3 теми: "Яка красива моя Україна". На основі зібраних даних були виявлені наступні переваги та недоліки змішаного навчання. Результати підсумкового контролю показали, що платорорма Zoom має більший спектр використання цифрових технологій. У другому пункті ми простежили технічне обладнання і виявили, що в навчальних аудиторіях менше збоїв з технікою. Також простежується позитивна динаміка в емоційній складовій уроку саме на офрлайн уроці. В ході дослідження, було з'ясовано, що на платформі Zoom учні мають більше доступу до різних джерел (інтернет ресурси, допоміжна література).

\section{Список літератури:}

1. Бернацкая М.В. Использование критического мышления при обучении иностранному языку студентов экономических вузов. Концепт. 2014. № 04 (апрель). С. 1-6.

2. Воробйова I.А. Формування соціокультурної компетенції учнів старшої школи засобами іноземної мов. Київ, 2003. 17 c.

3. Дюбанова О.Г. Технології критичного мислення на уроках англійської. СОГБОУ СПО. 2015. № 2. С. 2-6.

4. Загальноевропейські рекомендації з мовної освіти: вивчення, викладення, оцінювання / Науковий редактор укр. видання С.Ю. Ніколаєва. Київ : Ленвіт, 2003. 273 с. 
5. Матоніна Р.Д. Технологія розвитку критичного мислення. Графічні організатори. URL: https://naurok.com.ua/ prezentaciya-tehnologiya-rozvitku-kritichnogo-mislennya-grafichni-organizatori-114243.html

6. Общеевропейские компетенции владения иностранным языком: изучение, преподавание, оценка. Москва : Изд-во МГЛУ, 2003.

7. Рожина Т.Д., Степанова О.С. Уровневое обучение иностранным языкам в вузе: актуальные проблемы. Based on the experience of educational establishment, 2018. 3(21). C. 132-141.

8. Clandfield L. Global Coursebook L. Clandfield, R. Benn. Macmillan Publishers Limited. 2011. 200 p. (in English)

9. Competitive Advantage of Nations. New York : Free Press, 1998. 896 p.

10. Trim John. Gemeinsamer europäischer Referenzrahmen für Sprachen: lernen, lehren, beurteilen. Berlin ; München ; Wien ; Zürich ; New York, 2001. 244 p.

\section{References:}

1. Bernackaya M.V. (2014) Ispol'zovanie kriticheskogo myshleniya pri obuchenii inostrannomu yazyku studentov ekonomicheskih vuzov [The use of critical thinking in teaching a foreign language to students of economic universities]. Koncept, № 04 (april), pp. 1-6. (in Russian)

2. Vorobiova I.A. (2003) Formuvannia sotsiokulturnoi kompetentsii uchniv starshoi shkoly zasobamy inozemnoi mov [Formation of socio-cultural competence in high school with the help of a foreign comrade]. Kyiv, $17 \mathrm{p}$. (in Russian)

3. Diubanova O.H. (2015) Tekhnolohii krytychnoho myslennia na urokakh anhliiskoi [Technologies of critical thinking in English lessons]. SOGBOU SPO, no. 2, pp. 2-6. (in Ukrainian)

4. Zahalnoievropeiski rekomendatsii z movnoi osvity: vyvchennia, vykladennia, otsiniuvannia (2003) [European recommendations for language education: study, teaching, assessment] / Science editor ukr. vidannya S.Yu. Nikolaeva. Kyiv: Lenvit, 273 p. (in Ukrainian)

5. Matonina R.D. Tekhnolohiia rozvytku krytychnoho myslennia. Hrafichni orhanizatory [Technology for the development of critical thinking. Graphic organizers]. URL: https://naurok.com.ua/prezentaciya-tehnologiyarozvitku-kritichnogo-mislennya-grafichni-organizatori-114243.html (in Ukrainian)

6. Obshcheevropejskie kompetencii vladeniya inostrannym yazykom: izuchenie, prepodavanie, ocenka (2003) [Common European Framework of Reference for Languages: Learning, Teaching, Assessment]. Moscow: Izd-vo MGLU. (in Russian)

7. Rozhina T.D., Stepanova O.S. (2018) Urovnevoe obuchenie inostrannym yazykam v vuze: aktual'nye problemy. Based on the experience of educational establishment [Level learning of foreign languages at the university: topical problems], no. 3(21), pp. 132-141. (in Russian)

8. Clandfield L. (2011) Global Coursebook L. Clandfield, R. Benn. Macmillan Publishers Limited, 200 p. (in English)

9. Competitive Advantage of Nations (1998). New York: Free Press, 896 p.

10. Trim John (2001) Gemeinsamer europäischer Referenzrahmen für Sprachen: lernen, lehren, beurteilen. Berlin; München; Wien; Zürich; New York, 244 p. 